\title{
PENYULUHAN TEKNOLOGI IRIGASI TETES GUNA MENINGKATKAN PRODUKTIFITAS CABAI DI DESA IE SUUM KECAMATAN MESJID RAYA ACEH BESAR
}

\author{
Zaitun $^{1}$, Zulfahrizal $^{2}$ dan Elly Susanti ${ }^{3}$ \\ ${ }^{1}$ Jurusan Agroteknologi, Fakultas Pertanian, Universitas Syiah Kuala, Banda Aceh, Indonesia \\ ${ }^{2}$ Jurusan Teknik Pertanian, Fakultas Pertanian, Universitas Syiah Kuala, Banda Aceh, Indonesia \\ ${ }^{3}$ Jurusan Agribisnis, Fakultas Pertanian, Universitas Syiah Kuala, Banda Aceh, Indonesia \\ E-mail: zaitundara@unsyiah.ac.id
}

\begin{abstract}
ABSTRAK. Pengetahuan dan keterampilan Kelompok Tani Desa Ie Suum tentang teknik perakitan instalasi irigasi tetes untuk peningkatan produksi cabai masih terbatas. Tujuan dari kegiatan pengabdian ini untuk meningkatkan pengetahuan dan keterampilan kelompok tani tentang teknik perakitan instalasi irigasi tetes untuk peningkatan produksi cabai. Kendala utama dalam peningkatan produksi cabai adalah sulitnya tersedia air dan teknik irigasi yang tidak memadai. Disamping itu tanaman sangat mudah layu dan tumbuh kerdil. Mengatasi permasalahan tersebut dilakukan kegiatan pengabdian tentang teknik perakitan instalasi irigasi tetes untuk peningkatan produksi cabai. Kegiatan ini dilaksanakan di Desa Ie Suum Kecamatan Mesjid Raya Kabupaten Aceh Besar. Pelaksanaan kegiatan ini meliputi penyuluhan, demonstrasi teknik perakitan instalasi irigasi tetes dan pengaplikasian pada tanaman cabai. Target dan luaran dari kegiatan ini adalah meningkatkan pengetahuan dan keterampilan kelompok tani tentang teknik perakitan instalasi irigasi tetes untuk peningkatan produksi cabai, dapat meningkatkan pendapatan dan berbisnis cabai secara profesional dan berkelanjutan. Hasil pengabdian telah berhasil merakit penyiraman irigasi tetes untuk peningkatan produksi cabai di Desa Ie Suum Kecamatan Mesjid Raya Aceh Besar. Terjadi peningkatan pertumbuhan tanaman sampai 50\% dengan penggunaan irigasi tetes pada budidaya cabai.
\end{abstract}

Kata kunci: produksi; irigasi tetes; cabai; penyuluhan, berkelanjutan

ABSTRACT. The knowledge and skills of the Ie Suum Village Farmer Group regarding drip irrigation installation techniques to increase chili yield were still limited. The activity purpose was to increase the knowledge and skills of farmers regarding drip irrigation installation assembly techniques to increase chili yield. The problem to increasing chili yield was the difficulty of providing water and inadequate irrigation techniques. Besides, the plant was very easy to wither and grows stunted. To solve these problems, community service activities were carried out on drip irrigation installation techniques to increase chili yield. This activity at Ie Suum Village, Mesjid Raya Subdistrict, Aceh Besar District. The implementation includes counseling, demonstration of drip irrigation installation assembly techniques and its application to chili plants. The output was to increase the knowledge and skills of farmer groups about drip irrigation installation techniques to increase chili yield, increase income and do chili business professionally and sustainably. The activity results have succeeded in assembling drip irrigation to increase chili yield. There was an increase in plant growth by up to $50 \%$ with drip irrigation in chili cultivation.

Keywords: production; drip irrigation; chili; extention; sustainable

\section{PENDAHULUAN}

Desa Ie Suum merupakan salah satu desa yang terdapat di Kecamatan Mesjid Raya, Kabupaten Aceh Besar, dengan luas mencapai 584 ha. Secara letak dan posisi Desa Ie Suum berada pada ketinggian tempat 0,50 meter di atas permukaan laut. Berdasarkan data tahun 2018, jumlah penduduk Desa Ie Suum setelah tsunami 5000 jiwa. Masyarakat di Desa Ie Suum memiliki berbagai matapencaharian. Matapencaharian penduduk terdiri dari petani $45 \%$, nelayan $35 \%$, pegawai negeri $15 \%$ dan pedagang $5 \%$. Sebagian besar masyarakat tani di Desa Ie Suum sebelum dan pasca tsunami mengusahakan berbagai jenis sayuran seperti cabai, melon, sawi, selada, kacang panjang dan lain-lainnya (Bappeda Aceh Besar, 2018). Cabai merupakan salah satu komoditas yang memiliki nilai ekonomi tinggi (Hartati et al., 2018) dan memiliki nilai jual yang tinggi.
Hasil pengamatan yang dilakukan dan menjadi pusat perhatian adalah banyaknya petani yang berbudidaya cabai di Desa Ie Suum. Kebanyakan para petani tersebut bernaung dalam beberapa kelompok tani. Adapun kelompok tani yang sangat intensif membudidayakan cabai adalah Kelompok Tani Desa Ie Suum. Ironisnya pertumbuhan dan hasil tanaman cabai sangat memprihatinkan dan terkesan tidak terurus sebagaimana mestinya. Teknik budidaya cabai yang dilakukan oleh petani dan pemuda di desa tersebut belum memberikan produksi yang maksimal, yaitu maksimal hanya $1 \mathrm{~kg}$ per pohon, sedangkan produksi cabai pada umumnya $1,5 \mathrm{~kg}$ per pohon. Salah satu faktor yang menyebabkan rendahnya produksi cabai karena air yang tidak mencukupi dan belum ada fasilitas instalasi irigasi tetes. Ketidaktersediaan instalasi irigasi tetes dan kurangnya pasokan air untuk cabai pada musim kemarau menyebabkan produksi cabai 
tidak pernah meningkat yang dibudidayakan oleh petani. Mengatasi hal tersebut perlu diatasi dengan merakit instalasi irigasi tetes yang dapat digunakan oleh petani secara berkesinambungan.

Keunggulan lain, sistem irigasi pipa sederhana dengan sistem tetes ini cepat, mudah dirakit dan dapat dipergunakan berulang kali. Dalam kondisi iklim yang tidak menentu dan ketersediaan air yang sangat terbatas, teknologi pengairan dengan irigasi tetes pada budidaya tanaman cabai terutama di musim kemarau merupakan pilihan yang tepat.

Proses irigasi merupakan faktor penting untuk menghasilkan produk pertanian yang berkualitas (Pratilastiarso et al., 2021). Irigasi tetes dilakukan dengan tujuan untuk memanfaatkan ketersediaan air yang sangat terbatas secara efisien dan khususnya dirakit pada kondisi tanah yang memegang air dengan kandungan rendah (BPTP Aceh, 2018). Sistem irigasi tetes dapat langsung mensuplai kebutuhan air dan pupuk dengan cara menetes perlahan ke zona akar tanaman dengan kehilangan air yang minimum (Mistry et al, 2017). Sistem irigasi tetes diaplikasikan dengan menggunakan laju aliran air yang rendah dan tekanan rendah di emitor. Cara ini bisa menghemat air karena memang dirancang untuk memungkinkan air menetes perlahan langsung ke zona akar (Jondhale et al, 2017). Namun sistem filtrasi yang bagus diperlukan karena mudah tersumbat oleh padatan tersuspensi (reaksi kimia nutrisi) di air irigasi karena lubang air kecil (Prayong, 2013). Meskipun sistem irigasi tetes perlahan dan sedang membasahi tanah di dekat zona akar tanaman, sulit untuk mendistribusikan jumlah air yang sama ke tanaman di dalam lapangan (Arya et al, 2017).

Penggunaan irigasi tetes sangat diperlukan untuk mendukung peningkatan produktifitas cabai. Jika dikembangkan secara profesional cabai akan memberikan dampak peningkatan ekonomi petani secara signifikan. Harga cabai saat ini termasuk tinggi berkisar Rp. 50.000,--Rp. 90.000,-- per kg di wilayah Banda Aceh dan Aceh Besar. Disamping itu harga cabai tersebut sangat berfluktuatif dan cenderung meningkat juga. Keperluan cabai yang meningkat dalam industri makanan, membuat harga melambung dan sering tidak mencukupi kebutuhannya (Serambi Indonesia, 2019).

Desa Ie Suum merupakan salah satu desa di Kecamatan Mesjid Raya yang memiliki lahan sayuran termasuk cabai. Desa tersebut juga dikenal sebagai salah satu pemasok cabai untuk Kota Banda Aceh dan Aceh Besar. Jarak Desa Ie Suum tidak begitu jauh dari Universitas Syiah Kuala Darussalam Banda Aceh $(35 \mathrm{~km})$. Hal ini memungkinkan untuk memperoleh perhatian dan binaan yang intensif dari tim pengabdian masyarakat ini. Selanjutnya, di desa tersebut telah terbentuk kelompok tani namun belum diberdayakan secara maksimal. Oleh karena itu merupakan suatu peluang dan kesempatan kepada kami untuk melakukan pengabdian. Di samping itu banyak petani dan pemuda yang bertanam cabai dan sayuran lainnya dalam mengisi waktu luang. Permasalahan yang dihadapi Kelompok Tani Desa Ie Suum adalah belum memiliki pengetahuan dan keterampilan dalam merakit instalasi irigasi tetes yang dapat digunakan untuk meningkatkan hasil disebabkan antara lain: (1) Ketidaktahuan mereka terhadap sumber-sumber bahan dan alat yang diperlukan untuk merakit teknik irigasi tetes untuk peningkatan produksi cabai; (2) Ketidaktahuan mereka pada sistem pembuatan irigasi tetes tersebut tersebut untuk peningkatan hasil cabai; (3) Belum memiliki ilmu dan keterampilan untuk teknik perakitan instalasi irigasi tetes yang hemat air dan cara aplikasinya untuk peningkatan pertumbuhan dan hasil cabai; (4) Ketidaktahuan mereka tentang aplikasi dan pemasangan irigasi tetes tersebut untuk peningkatan pertumbuhan dan hasil cabai.

Tujuan dari pengabdian berbasis produk ini untuk merakit irigasi tetes untuk peningkatan produksi cabai. Manfaat lainnya dari pengabdian ini untuk Kelompok Tani Desa Ie Suum antara lain: (1) Dengan kegiatan pengabdian kepada masyarakat ini diharapkan 100\% dari anggota Kelompok Tani Desa Ie Suum memiliki ilmu dan mengerti tentang teknik perakitan irigasi tetes hemat air; (2) Dengan kegiatan ini diharapkan Kelompok Tani Desa Ie Suum dapat merakit irigasi tetes sebanyak 5000-10.000 unit untuk peningkatan produksi cabai dan mengerti bagaimana mengaplikasikan untuk tanaman cabai; (3) Dengan kegiatan pengabdian ini diharapkan Kelompok Tani Desa Ie Suum mampu meningkatkan hasil sekaligus dapatmeningkatkan perekonomian dan kesejahteraan mereka; (4) Dengan adanya kegiatan ini diharapkan 95\% masyarakat dapat menggalakkan pertanian hemat air dan kelestarian lingkungan; dan (5) Dengan keberhasilan pembuatan dan penggunaan irigasi tetes di Desa Ie Suum diharapkan masyarakat desa sekitar dapat mencontoh dan mampu menghasilkan peningkatan produksi cabai sebesar 50\%.

\section{METODE}

Merujuk pada hasil analisis situasi dan potensi yang dimiliki oleh Desa Ie Suum yang didukung oleh ilmu dan pengalaman yang miliki, maka pada kegiatan PKM ini menawarkan solusi yang mudah, murah, dan dapat dilaksanakan secara terus menerus dan berkelanjutan. Solusi tersebut adalah teknik perakitan instalasi irigasi tetes untuk peningkatan pertumbuhan dan hasil cabai. Metode yang dilakukan dalam pemberdayaan Kelompok Tani Desa Ie Suum tentang teknik perakitan instalasi irigasi tetes sebagai berikut : 
(1) Memberikan penyuluhan kepada Kelompok Tani Desa Ie Suum tentang teknik perakitan instalasi irigasi tetes dan pemanfaatannya untuk peningkatan pertumbuhan dan hasil tanaman cabai;

(2) Mendemonstrasikan praktek cara teknik perakitan instalasi irigasi tetes, dalam hal ini kami membimbing Kelompok Tani Kelompok Tani Desa Ie Suum untuk teknik perakitan instalasi irigasi tetes hemat air;

(3) Setelah selesai pembuatan irigasi tetes tersebut, dilanjutkan dengan pemanfaatannya untuk peningkatan produksi cabai. Dalam hal ini fokus utama kami adalah bagaimana cara aplikasi dan pemasangan yang tepat di lahan cabai.

Secara detail teknik pembuatan irigasi tetes (Suhadi, 2017) sebagai berikut :

(1) Pipa paralon dilubangi dengan boor diameter 4,5 $\mathrm{mm}$ dengan jarak yang disesuaikan dengan jarak tanaman;

(2) Pasangkan nepel pada tiap lubang dengan lem menggunakan lem PVC;

(3) Selang aquarium sepanjang $\pm 40 \mathrm{~cm}$ yang telah dipasang manik-manik pada ujungnya disambungkan pada nepel dan diarahkan ke masing-masing tanaman. Untuk mengalirkan air dari sumbernya diperlukan pompa air, juga dilengkapi krandan pipa konektor untuk sambungan;

(4) Pengairan atau penyiraman dilakukan dua kali sehari, pagi dan petang dengan lama penyiraman tergantung fase pertumbuhan tanaman;

(5) Pada fase pertumbuhan penyiraman dilakukan selama 10 menit, pada fase pembungaan dan pembuahan 11 menit dan fase panen 12 menit.

Dengan asumsi bahwa kebutuhan air per tanaman, pada fase pertumbuhan adalah $480 \mathrm{ml} /$ tanaman, fase pembungaan/pembuahan $520 \mathrm{ml} /$ tanaman dan fase panen sebanyak $540 \mathrm{ml} /$ tanaman.

Model irigasi tetes yang akan didemonstrasikan pada lahan cabai seperti terlihat pada Gambar 1.

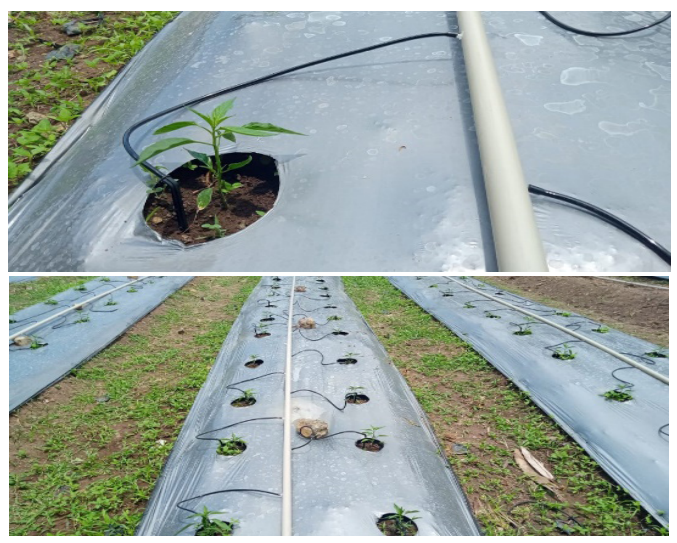

Sumber: dokumen 2020

Gambar 1. Aplikasi Irigasi Tetes pada Lahan Usahatani Cabai

\section{HASIL DAN PEMBAHASAN}

Dari hasil kegiatan pengabdian kepada masyarakat ini menghasilkan target dan luaran yang bermanfaat untuk Kelompok Tani Desa Ie Suum tentang teknik perakitan irigasi tetes untuk peningkatan produksi cabai pada saat ini dan masa yang akan datang. Adapun target luaran yang dihasilkan, antara lain:

(1) Kelompok Tani Desa Ie Suum telah meningkat pengetahuan dan keterampilan serta telah memiliki ilmu dan mengerti tentang tentang teknik perakitan irigasi tetes untuk peningkatan produksi cabai.

(2) Kelompok Tani Desa Ie Suum dapat membuat irigasi tetes untuk peningkatan produksi cabai.

(3) Kelompok Tani Desa Ie Suum mampu mengaplikasi irigasi tetes pada tanaman cabai dan penampilan cabai yang tumbuh di lapangan sangat baik;

(4) Masyarakat telah menggalakkan pertanian yang memnggunakan teknologi tepat guna dalam budidaya tanaman cabai.

Kegiatan PKM menjadi sarana untuk berbagi ilmu dan keterampilan kepada Kelompok Tani Desa Ie Suum. Dampak lainnya bagi kelompok sasaran telah membuka wawasan baru tentang teknik perakitan irigasi tetes dan penggunaannya untuk kegiatan budidaya tanaman cabai (Gambar 2). Disamping itu kegiatan ini juga telah meningkatkan pendapatan kelompok sasaran dengan penjualan produk cabai yang mereka hasilkan. Secara terukur $75 \%$ dari kelompok sasaran telah dapat menyerap semua adopsi inovasi yang diberikan, hal ini tergambarkan dengan kemampuan kelompok sasaran dalam merakit irigasi tetes dan mengaplikasikan pada tanaman cabai (Gambar 2).

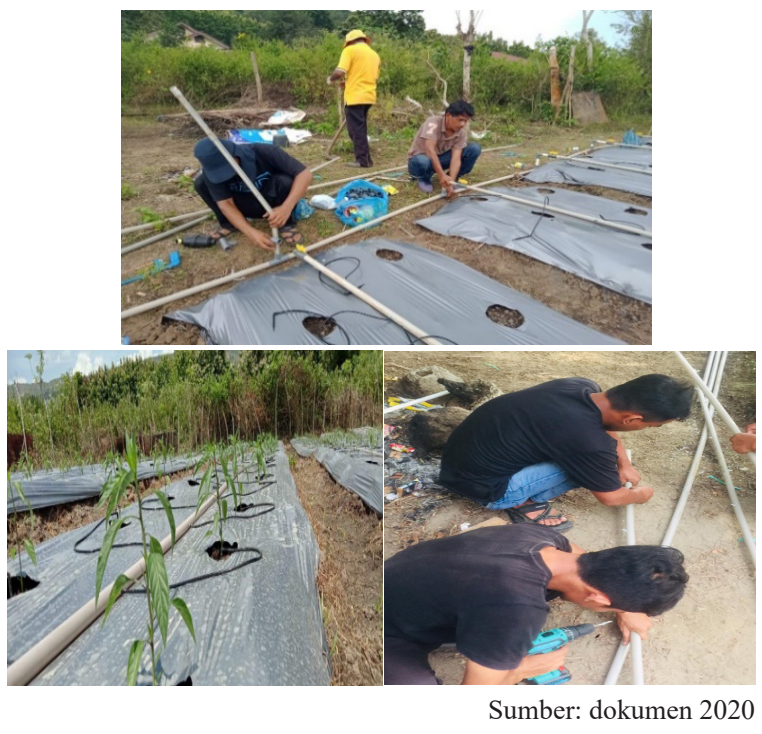

Gambar 2. Perakitan rangkaian dan pemasangan instrument irigasi tetes di lahan cabai

Penyuluhan Teknologi Irigasi Tetes Guna Meningkatkan Produktifitas Cabai di Desa Ie Suum Kecamatan Mesjid Raya Aceh Besar (Zaitun, Zulfahrizal dan Elly Susanti) 
Hasil pengabdian yang dilaksanakan sejalan dengan beberapa penelitian yang menunjukkkan bahwa penggunaan irigasi tetes pada tanaman cabai akan lebih meningkatkan produksi cabai. Disamping itu rancangan irigasi tetes juga membuat penghematan dalam penggunaan air sampai $50 \%$ dan pengairan yang diberikan akan lebih tepat pada sasaran tanaman yang diberikan irigasi tetes. Penggunaan irigasi tetes pada tanaman cabai dapat meningkatkan hasil sampai $50 \%$, disamping itu dapat menghemat tenaga dan membuat petani dapat mererapkan teknologi tepat guna dalam berbudiya termasuk budidaya cabai. Secara khusus dapat dilaporkan penggunaan irigasi tetes yang tepat pada tanaman cabai sangat mempengaruhi pertumbuhan dan hasil. Umumnya tanpa penggunaan irigasi tetes hasil maksimal cabai yang didapatkan hanya berkisar $1 \mathrm{~kg}$ per pohon dan setelah penerapan irigasi tetes produksi cabai dapat mencapai $1,5 \mathrm{~kg}$ per pohon atau meningkat sampai $50 \%$ dengan penggunaan irigasi tetes.

Khusus pada tanaman yang diberikan irigasi tetes mempunyai sifat ketahanan yang lebih dibandingkan dengan tanpa irigasi tetes. Selain itu performansi tanaman di lapangan sangat baik dan tidak terserang penyakit (Gambar 3). Kondisi ini memungkinkan karena tanaman yang memperoleh cukup air dan sesuai dengan kebutuhan akan terhindar dari serangan penyakit dan hama. Tidak ada kendala yang berarti dalam pelaksanaan ini, kecuali pengaturan waktu pertemuan lapangan harus disepakati dengan kelompok sasaran.

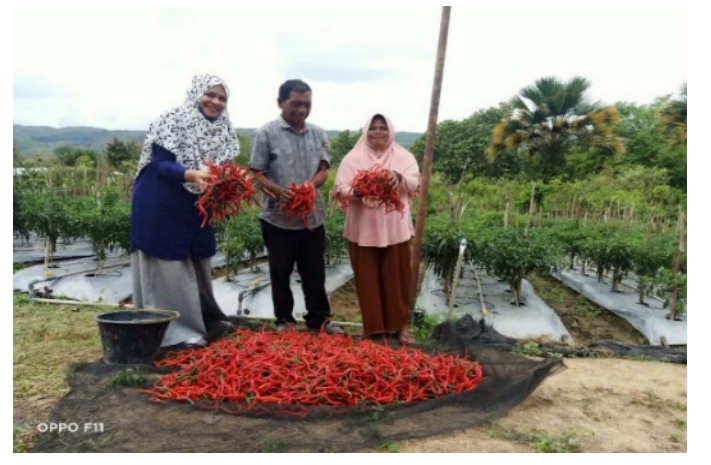

Sumber: dokumen 2020

Gambar 3. Produksi cabai meningkat dengan penyiraman irigasi tetes

\section{SIMPULAN}

Kesimpulan pada kegiatan pengabdian meliputi :

1. Kelompok Tani Desa Ie Suum telah meningkat pengetahuan dan keterampilan serta telah memiliki ilmu dan mengerti tentang tentang teknik perakitan irigasi tetes dan pengaplikasiannya untuk peningkatan produksi cabai.

2. Terjadi peningkatan produksi cabai sampai $50 \%$ dengan penggunaan irigasi tetes pada budidaya tanaman cabai yang dilakukan oleh Kelompok Tani Desa Ie Suum.
3. Petani di desa Ie Suum telah menerapkan pertanian melalui penggunaan teknologi tepat guna dengan penggunaan irigasi tetes yang digunakan pada budidaya tanaman cabai.

\section{UCAPAN TERIMAKASIH}

Penulis mengucapkan terima kasih kepada Lembaga Penelitian dan Pengabdian Kepada Masyarakat Universitas Syiah Kuala yang telah mendanai kegiatan pengabdian kepada masyarakat sesuai dengan Surat Perjanjian Penugasan Pelaksanaan Pengabdian Kepada Masyarakat Berbasis Produk.

\section{DAFTAR PUSTAKA}

Arya C K, Purohit RC, Dashora L K, Singh P K and Kothari M. 2017. Performance evaluation of drip irrigation systems. International Journal of Current Microbiology and Applied Sciences, 6(4) 2287-2292.

Bappeda Aceh Besar. 2018. Aceh Besar Dalam Angka 2017. Bappeda Kabupaten Aceh Besar, Aceh Besar.

BPTP Aceh. 2018. Petunjuk Teknis Cabai. Penerbit BPTP Aceh, Banda Aceh.

Hartati, S, E. Yulia dan L. Djaya. 2018. Sosialisasi dan Pelatihan Pengendalian Antraknosa Pada Tanaman Cabai Menggunakan Khamir Sebagai Komponen Pengendalian Ramah Lingkungan. Dharmakarya Vol 7, No 2. Juni. Hal 80-83.

Jondhale A S, Bhosale V P and Takate V S. 2017. Irrigation System and Its Methods. International Journal for Research in Applied Science and Engineering Technology, 5(5) 1549-1552.

Mistry P, Akil M, Suryanarayana T M V and Parekh F P. 2017. Evaluation Of Drip Irrigation System For Different Operating Pressures. International Journal OfAdvance Engineering And Research Development, 72(4) 2348-4470.

Serambi Indonesia. 2019. Harga Cabai Setara Daging. Https://aceh.tribunnews.com/2019/07/ 26/ harga-cabai-setara-daging. Diakses 19 September 2019.

Suhadi M. 2017. Rancang bangun sistem irigas ialur (furrox irigation). FakultasTehnik Pertanian UGM Yogyakarta

Pratilastiarso, J., Diana, L., Tridianto, E., dan Safitra, A.G. 2021. Pemasangan Smart Solar Water Pump Sebagai Alat Irigasi Sawah Di Desa Gayam Kabupaten Bojonegoro. Jurnal Pengabdian Kepada Masyarakat Volume 27 No. 1, Januari-Maret 2021. 